Sección Control / Control

Artículos de investigación / Research paper

\title{
Impact of resistance to fenitrothion and esfenvalerate on the control of Rhyzopertha dominica (Coleoptera: Bostrichidae) in stored wheat
}

\author{
Impacto de la resistencia al fenitrotion y al esfenvalerato sobre el control de \\ Rhyzopertha dominica (Coleoptera: Bostrichidae) en trigo almacenado
}

\section{JAVIER ALBERTO VÁSQUEZ-CASTRO ${ }^{1}$; GILBERTO CASADEI DE BAPTISTA ${ }^{2}$; CASIMIRO DIAS GADANHA JR. ${ }^{3}$; JULIO CESAR BRACHO-PÉREZ ${ }^{4}$}

\begin{abstract}
${ }^{1}$ Ph. D. Entomology, Departamento de Entomología, Universidad Nacional Agraria La Molina, Av. La Molina s/n La Molina, Lima, Perú, jaque@lamolina.edu. pe, https://orcid.org/0000-0003-3407-6938. ${ }^{2} \mathrm{Ph}$. D. Entomology, Departamento de Entomologia e Acarologia, Escola Superior de Agricultura "Luiz de Queiroz", Universidade de São Paulo, ESALQ-USP, Piracicaba, São Paulo, Brazil, gilcasadei@usp.br, https://orcid.org/0000-0003-1810-4804. ${ }^{3}$ Ph. D. Agricultural Engineering, Departamento de Engenharia de Biossistemas, Escola Superior de Agricultura "Luiz de Queiroz", Universidade de São Paulo, ESALQ-USP, Piracicaba, São Paulo, Brazil, cdgadanh@usp.br, https://orcid.org/0000-0002-5476-1388. ${ }^{4}$ M. Sc. Chemical Engineering, Universidad Nacional Tecnológica de Lima Sur, Lima, Perú, jbracho@untels.edu.pe, https://orcid.org/0000-0001-9563-9429.
\end{abstract}

\section{Corresponding author}

Javier Alberto Vásquez-Castro. Ph. D. Entomology, Departamento de Entomología, Universidad Nacional Agraria La Molina, Av. La Molina s/n La Molina, Lima, Perú, jaque@lamolina. edu.pe, https://orcid.org/0000-0003-3407-6938.

\section{Suggested citation}

VÁSQUEZ-CASTRO, J. A.; BAPTISTA, G. C.; GADANHA Jr., C. D.; BRACHO-PÉREZ, J. C. 2020. Impact of resistance to fenitrothion and esfenvalerate on the control of Rhyzopertha dominica (Coleoptera: Bostrichidae) in stored wheat. Revista Colombiana de Entomología 46 (2): e 7612. https://doi.org/10.25100/socolen. v46i2.7612

Received: 27-Feb-2019

Accepted: 23-Feb-2020

Published: 28-Dec-2020

Revista Colombiana de Entomología ISSN (Print): 0120-0488

ISSN (On Line): 2665-4385

https://revistacolombianaentomologia.univalle.edu.co

Open access

(c) (i) (2) (2) BY-NC-SA 4.0

Publishers: Sociedad Colombiana de Entomología SOCOLEN (Bogotá, D. C., Colombia) https://www.socolen.org.co

Universidad del Valle (Cali, Colombia)

https://www.univalle.edu.co

(C) 2020 Sociedad Colombiana de Entomología SOCOLEN y Universidad del Valle
Abstract: Insecticides resistance can significantly compromise the control programs of Rhyzopertha dominica (Coleoptera: Bostrichidae), one of the main wheat pests in warehouses. The objectives of this work were to study the occurrence of resistance to fenitrothion and esfenvalerate in two Brazilian populations of $R$. dominica from Santa Rosa (SR lineage) and Campo Grande (CG lineage), as well as the insecticidal effect and residual action of these insecticides when used alone or as a mixture in stored wheat. The application system was calibrated to provide grain treatment at theoretical concentrations of 10 and/or $0.5 \mathrm{mg} . \mathrm{kg}^{-1}$ fenitrothion and esfenvalerate, respectively. By comparing the fitted mortality curves for lineages within insecticides, as well as insecticides within lineages significant differences were observed in all cases. Esfenvalerate was ineffective in controlling $R$. dominica. The SR lineage of $R$. dominica was more resistant to the insecticides tested than the CG lineage. The number of individuals in the $\mathrm{F} 1$ offspring of $R$. dominica was dependent on the lineage, insecticide, and on the time after the application of insecticide. In the untreated grains (control), the CG lineage had a greater number of progeny than the SR lineage, while the opposite was verified in the grains treated. Fenitrothion and esfenvalerate are not useful for the control of $R$. dominica. Factors influencing control of $R$. dominica are discussed in this work.

Keywords: Lesser grain borer, stored grains, bioassay, insecticides, hormoligosis.

Resumen: La resistencia a los insecticidas puede comprometer significativamente los programas de control de Rhyzopertha dominica (Coleoptera: Bostrichidae), una de las principales plagas del trigo almacenado. Los objetivos de este trabajo fueron estudiar la ocurrencia de resistencia al fenitrotion y esfenvalerato en dos poblaciones brasileñas de $R$. dominica procedentes de Santa Rosa (raza SR) y Campo Grande (raza CG), así como el efecto insecticida y la acción residual de estos insecticidas cuando utilizados solos o en mezcla, en trigo almacenado. El sistema de aplicación se calibró para el tratamiento de los granos con concentraciones teóricas de $10 \mathrm{y} / \mathrm{o} \quad 0,5 \mathrm{mg} \cdot \mathrm{kg}^{-1}$ de fenitrotion y esfenvalerato, respectivamente. Al comparar las curvas de mortalidad ajustadas para las razas dentro de los insecticidas, así como los insecticidas dentro de las razas, se observaron diferencias significativas en todos los casos. El esfenvalerato fue ineficaz en el control de $R$. dominica. La raza SR de $R$. dominica fue más resistente a los insecticidas estudiados que su contraparte CG. El número de individuos en la progenie F1 de $R$. dominica dependió de la raza, del insecticida y del tiempo después de la aplicación del insecticida. En los granos no tratados (testigo), la raza CG tuvo un número mayor de progenie que la SR, mientras que se verificó lo contrario en los granos tratados. Los insecticidas fenitrotion y esfenvalerato no son útiles para el control de $R$. dominica. Los factores que influyeron en el control de $R$. dominica se discuten en este trabajo.

Palabras clave: Barrenador pequeño del grano, granos almacenados, bioensayo, insecticidas, hormoligosis.

\section{Introduction}

According to estimated data supplied by FAO and the Brazilian Ministry of Agriculture, Livestock and Food Supply, $10 \%$ of grains produced in Brazil are lost for insect attack when in storage (Beskow and Deckers 2002a). Rhyzopertha dominica (F., 1792) predominates among pests attacking wheat grains, being considered primary pest for having the ability to perforate the whole-grain teguments (Gallo et al. 2002). 
Due to problems caused by insects during warehousing, chemical-substances have been used in Brazil to control these pests. However, inadequate application of these substances has favored the evolution of insecticide resistance (Pacheco et al. 1993; Lorini and Galley 1999; Ribeiro et al. 2003) and the occurrence of pesticide residues in food, thus putting consumers' health at risk (Vásquez-Castro et al. 2020). Concordantly, Afful et al. (2018) indicated that excessive use of fumigation substances contributes to the genetic development of phosphine resistance in wheat pests. On the other hand, sub-lethal amounts of insecticide can encourage pest population growth (hormoligosis) (Kuenen 1958; Luckey 1968; Morse 1998). A number of studies have shown greater susceptibility of $R$. dominica to pyrethroids (Bengston et al. 1987; Arthur 1999; Paudyal et al. 2016). However, in Brazil, resistance has been reported of $R$. dominica to pyrethroids (Lorini and Galley 1999) and to organophosphates (Pacheco et al. 1991; Guedes et al. 1996). Likewise, Afful et al. 2018 demonstrated phosphine resistance in $R$. dominica throughout North America, which could result in a challenge for the application of this substance.

Among registered insecticides for the treatment of stored wheat, in Brazil, are the organophosphate fenitrothion and the pyrethroid esfenvalerate (Agência Nacional de Vigilância Sanitária 2020a, 2020b). Several studies have demonstrated the high efficiency of fenitrothion in controlling pests of stored products (Champ et al. 1969; Hyari et al. 1977; Thaung and Collins 1986; Collins et al. 1993; Pereira et al. 1997). Furthermore, there are few studies on the effectiveness of esfenvalerate in warehouse pest-control (Pinto Jr. et al. 1997; Pereira et al. 1997). Esfenvalerate is a relatively new insecticide which has physicochemical properties similar to fenvalerate, however it presents high efficiency in the control of insects because it holds more than $80 \%$ of isomers with insecticidal activity differently to a $22 \%$ of fenvalerate (Adelsbach and Tjeerdema 2003).

In toxicological studies an assessment of population growth supplies more precise information as of targeted and non-targeted organisms, than that of lethal dose/concentration $50\left(\mathrm{LD}_{50}, \mathrm{LC}_{50}\right)$ (Stark and Banks 2003). With this respect, several studies have shown the importance of evaluating the production of offspring in grain protection experiments using residual insecticides (Evans 1985; Daglish et al. 1996; Arthur 1999; Daglish and Wallbank 2005; Athanassiou 2006). In addition to these evaluations, (Collins et al. 1993) suggests that studies on resistance should include tests on inert surface and on treated grains in order to get a better understanding of the importance of resistance. The objectives of this work were to study the occurrence of resistance to fenitrothion and esfenvalerate in two Brazilian populations of $R$. dominica from Santa Rosa (SR lineage) and Campo Grande (CG lineage), as well as the insecticidal effect and residual action of these insecticides when used alone or as a mixture in stored wheat.

\section{Materials and methods}

Insects. Two populations of $R$. dominica were collected from storage units in Campo Grande, Mato Grosso do Sul (CG lineage) and Santa Rosa, Rio Grande do Sul (SR lineage) in 2010. At the time of collection, the population from Campo Grande was effectively controlled by protective insecticides of stored grains, while in Santa Rosa the control of these pests was a failure. The studied species were reared on insecticide-free wheat grains until the installation of the experiments.
Insecticides. In order to tests the effectiveness of the insecticides, we used the following formulations: Sumigranplus ${ }^{\circledR}$ $(500 \mathrm{~g}$ fenitrothion $+25 \mathrm{~g}$ esfenvalerate per liter of the commercial product), Sumigran ${ }^{\circledR}$ (500 $\mathrm{g}$ fenitrothion per liter of the commercial product) and Sumidan ${ }^{\circledR}$ (25 g esfenvalerate per liter of the commercial product) were used. To estimate $\mathrm{LC}_{50}$ analytical standards of fenitrothion (99.1\% a.i.) and esfenvalerate (100\% a.i.) were utilized, (Iharabras S.A., Sorocaba, SP, Brazil).

Grain treatment and bio-assays. Grains were treated in order to obtain the theoretical concentration of 10 and 0.5 mg. $\mathrm{kg}^{-1}$ fenitrothion and/or esfenvalerate, respectively, as recommended by the manufacturer on the labels. The method of application in use was proposed by (Vásquez-Castro et al. 2007a, 2007b). Three replications were performed for each insecticide. Temperature values and relative humidity during spraying were $18{ }^{\circ} \mathrm{C}$ and $72 \%$, respectively. After grain-spraying, they were placed into kept-open plastic bags and stored in the laboratory under uncontrolled conditions of temperature and relative humidity.

For the effectiveness tests, $40 \mathrm{~g}$ of grains were placed into plastic pots and infected with 40 adult insects aged 10 to 20 days. After this, the pots were closed with voile fabric and elastic and maintained in the laboratory under uncontrolled environmental conditions. Mortality evaluation was accomplished 15 days after infestation, considering dead the immobile individuals, that is, unable to move even when stimulated by an incandescent light source placed a few centimeters from them (Vásquez-Castro et al. 2012). The effectiveness experiments were installed as of 15 days, 30 days and subsequently at monthly intervals until mortality ceased. After mortality evaluation occurred, all individuals of $R$. dominica were eliminated, either dead or alive, and grains were maintained for 90 days to assess the number of emerged progeny (F1) during this period.

Bio-assays to estimate $\mathrm{LC}_{50}$ were adapted from studies of resistance of $R$. dominica to insecticides (Guedes et al. 1996; Guedes et al. 1997; Guedes and Zhu 1999; Fragoso et al. 2003). Adult insects aged 10 to 20 days were evaluated by exposure to dry insecticide-residuals on the inner surface of glass vials (2.3 $\mathrm{cm}$ diameter $\mathrm{x} 4 \mathrm{~cm}$ height). Five milliliters of the insecticide solutions were transferred to the tubes and then evaporated by air-moving assistance previously dried on blue silica-gel desiccant filter. Afterwards, 25 individuals were placed inside the tubes and maintained under controlled conditions $\left(25 \pm 1{ }^{\circ} \mathrm{C}\right.$ temperature and $74 \%$ relative humidity). In order to prevent insects from leaving the treated area, a thin layer of liquid vaselineage was spread over the border of treated and untreated areas of the tube. Mortality evaluation was carried out $24 \mathrm{~h}$ after the installation of the experiments, using the same criterion of the effectiveness tests. Four replications for each concentration and five or six concentrations were used in each bioassay. Control treatment was also included but received only the solvent (acetone). Concentration-mortality data were submitted to Probit for analysis (Leora Software 2016).

Statistical analysis. As the response variable of the experiment (number of dead insects, $\mathrm{d}=40$ insects) has binomial distribution, effectiveness tests data were analyzed by using logistic regression, that is, through the logistic procedure of SAS (SAS 1999). The model $\eta=\alpha_{\mathrm{ij}}+\beta_{\mathrm{ij}} \mathrm{x}$ was practiced; whose lineagear predictor includes different intercepts and inclination coefficients (related to time after insecticide 
application) for the combinations of insecticides and lineages. Based on this model, estimates were calculated for $\alpha_{\mathrm{s}}, \beta_{\mathrm{s}}$ and lethal time 50 , when mortality of $50 \%$ insects occurred. For progeny data analyses (F1), it was first considered that this variable had a Poisson distribution since it is a count, but due to data over-dispersion, the response variable was evaluated using the negative binomial distribution, through GENMOD procedure of SAS (1999). Lineage $R$. dominica lineage and insecticide (categorical variables) and time after insecticide application (quantitative variable) were considered explanatory variables.

\section{Results}

Effectiveness experiments. The model in use indicates the existence of significant differences between $\alpha$ and $\beta$ as to insecticides and pest lineages. Table 1 shows the estimated values of these two parameters for each combination of insecticide and pest lineage, as well as lethal time to kill 50 $\%$ of insects, based upon estimates of these two parameters. Deviances and $\chi^{2}$ statistics indicate that the lineagear logistic model fit well in the 6 models of the combination of insecticide and pest lineages, and the lower significance level was 0.3171 for the mixture of insecticides fenitrothion + esfenvalerate used in the CG lineage of $R$. dominica. Moreover, a significant lineagear regression effect $(\mathrm{P}>0.05)$ occurred in all cases; that is, a time-effect happened after insecticide application on insect mortality.

In some cases, it was not possible to estimate the wanted-lethal time so as to reach $50 \%$ mortality $\left(\mathrm{LT}_{50}\right)$ because values lower than $50 \%$ were obtained at the beginning of the experiments, as per SR lineage exposed to insecticides fenitrothion, esfenvalerate and fenitrothion + esfenvalerate mixture.

Comparing the adjusted curves of lineages within insecticides, as well as insecticides within lineages, significant differences $(\mathrm{P}<0.0001)$ were observed in all cases, the same happens when comparing curves of insecticides within lineages. Figures 1 to 3 depict mortality observed and adjusted curves, on each, and for each insecticide and each lineage. Comparison amid more similar mortality curves as to those within each insecticide by way of difference of deviances displayed significant dissimilarities $(\mathrm{P}<0.05)$ in curves. The control showed $0.13 \%$ average mortality.

Table 2 presents the characterization of susceptibility of the studied lineages to fenitrothion and esfenvalerate.

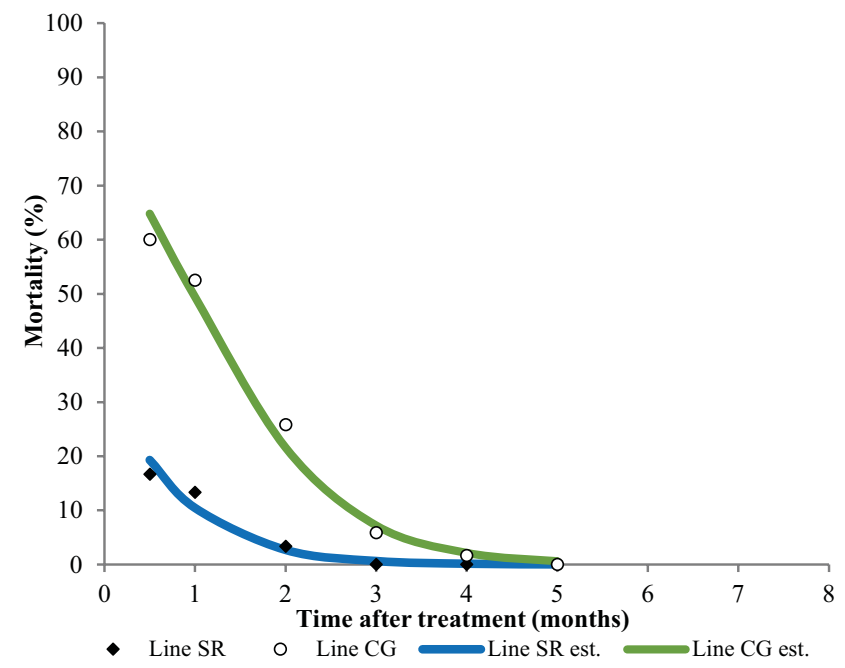

Figure 1. Mortality of two lineages of Rhyzopertha dominica and adjusted curves using the lineagear logistic model over time after treatment of grains with fenitrothion.

One can note that the results obtained through dry-film bio-assays meet results of effectiveness tests. Regarding fenitrothion, the SR lineage of $R$. dominica was 1.6 times more resistant than the CG lineage. As for esfenvalerate, the SR lineage of $R$. dominica was 8.9 more resistant than the CG lineage.

In all cases the tested populations presented $\mathrm{LC}_{50}$ heterogeneity lower than 4, except for the SR lineage of $R$. dominica treated with esfenvalerate. Notwithstanding, for the same combination of lineage and insecticide, the lowest angular coefficient and the higher confidence interval amplitude were obtained. The SR lineage showed slight response to the increase of esfenvalerate concentration, up to the state in which the increase in insecticide concentration did not increase mortality. This might explain the output result.

In general, $R$. dominica was more susceptible to esfenvalerate than to fenitrothion. Considering only the results of the dry film test, one can affirm that esfenvalerate is effective in controlling $R$. dominica, but the grain protection experiments demonstrated the contrary. In this sense, performing both types of bio-assays (grains treatment and dry film) is recommended in order to characterize the susceptibility of pests to the insecticides used to protect stored grains.

Table 1. Residual degrees of freedom, deviances and $\chi^{2}$, for the lineagear logistic model, estimate of $\alpha$ and $\beta$ parameters, probability descriptive level for the lineagear regression effect and lethal time $50\left(\mathrm{TL}_{50}\right)$.

\begin{tabular}{|c|c|c|c|c|c|c|c|c|c|}
\hline \multirow{2}{*}{ Lineage } & \multirow{2}{*}{ DF } & \multicolumn{2}{|c|}{ Deviance } & \multicolumn{2}{|c|}{$\chi^{2}$} & \multicolumn{2}{|c|}{ Parameters } & \multirow{2}{*}{$\begin{array}{c}\text { Lineagear } \\
\text { regression }\left(\operatorname{Pr}>\chi^{2}\right)\end{array}$} & \multirow{2}{*}{$\begin{array}{c}\mathbf{L T}_{50} \\
\text { (months) }\end{array}$} \\
\hline & & Value & $\operatorname{Pr}>\chi^{2}$ & Value & $\operatorname{Pr}>\chi^{2}$ & $\alpha$ & $\boldsymbol{\beta}$ & & \\
\hline \multicolumn{10}{|c|}{ Fenitrothion } \\
\hline SR & 16 & 5.92 & 0.9890 & 5.00 & 0.9957 & -0.713 & -1.434 & $<0.0001$ & - \\
\hline $\mathrm{CG}$ & 16 & 8.16 & 0.9441 & 6.66 & 0.9793 & 1.244 & -1.266 & $<0.0001$ & 0.98 \\
\hline \multicolumn{10}{|c|}{ Esfenvalerate } \\
\hline SR & 22 & 13.29 & 0.9247 & 11.21 & 0.9716 & -1.666 & -0.587 & $<0.0001$ & - \\
\hline $\mathrm{CG}$ & 22 & 6.45 & 0.9995 & 6.47 & 0.9995 & 0.508 & -0.305 & $<0.0001$ & 1.67 \\
\hline \multicolumn{10}{|c|}{ Fenitrothion + Esfenvalerate } \\
\hline SR & 25 & 14.12 & 0.9596 & 13.43 & 0.9708 & -0.553 & -0.229 & $<0.0001$ & - \\
\hline CG & 25 & 27.25 & 0.3436 & 27.80 & 0.3171 & 3.674 & -0.638 & $<0.0001$ & 5.76 \\
\hline
\end{tabular}




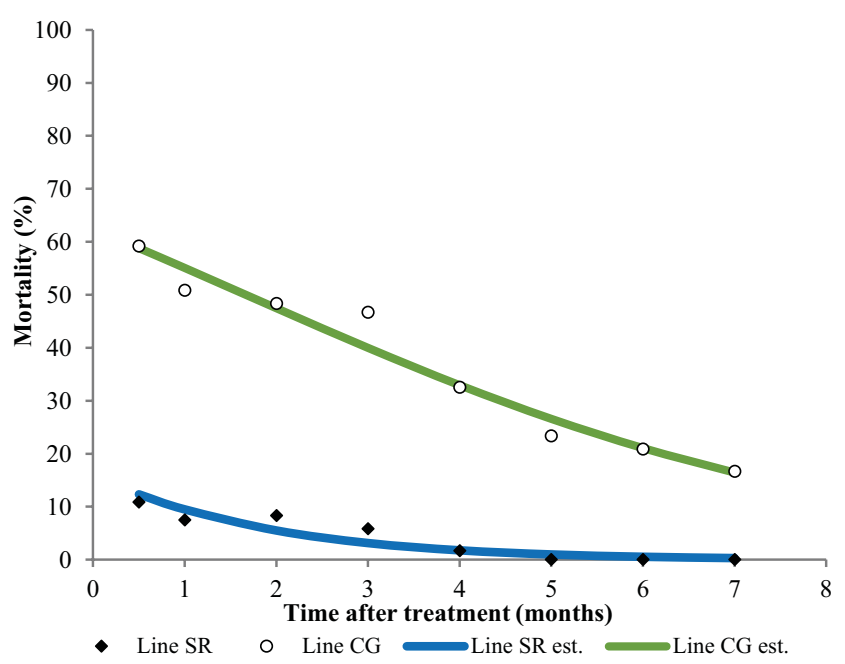

Figure 2. Mortality of two lineages of Rhyzopertha dominica and adjusted curves using the lineagear logistic model over time after treatment of grains with esfenvalerate.

Potentiation effect occurred for the fenitrothion + esfenvalerate mixture in controlling the two lineages of $R$. dominica. In the CG lineage, the toxic effect of the additive type between insecticides was initially observed; as of the second month after treatment, the toxic effect was potentiation. In the SR lineage, control levels were very low; and so, this potentiate-effect was observed from the beginning of the experiments.

F1 progeny of Rhyzopertha dominica. Considering as a random component the Poisson distribution, and all the explanatory variables and interactions, the starting analysis presented residual deviance (7513) and $\chi^{2}(7243)$ as very high compared to the 260 residual degrees of freedom, indicating over-dispersion of data. Thus, the negative binomial distribution was considered as a random component of the model, that is, one of the ways to analyze over-dispersed tallied data. The adjustment of the negative binomial model presented residual deviance (317.9) and $\chi^{2}$ (249.7) values closer to the 260 residual degrees of freedom.

Table 3 shows the existence of significant effect $(\mathrm{P}<0.01)$ of all the evaluated causes of variation, including triple interaction. This indicates that the number of individuals of $F 1$ progeny depends on the lineage of $R$. dominica, insecticide and time after insecticide application.

Table 4 presents the estimates of $\alpha$ and $\beta$ parameters of the negative binomial lineagear model for the combination insecticide-lineage.

The estimated value of number of insects of $\mathrm{F} 1$ progeny is determined by $e^{\alpha+\beta x}$, for each combination of insecticide and

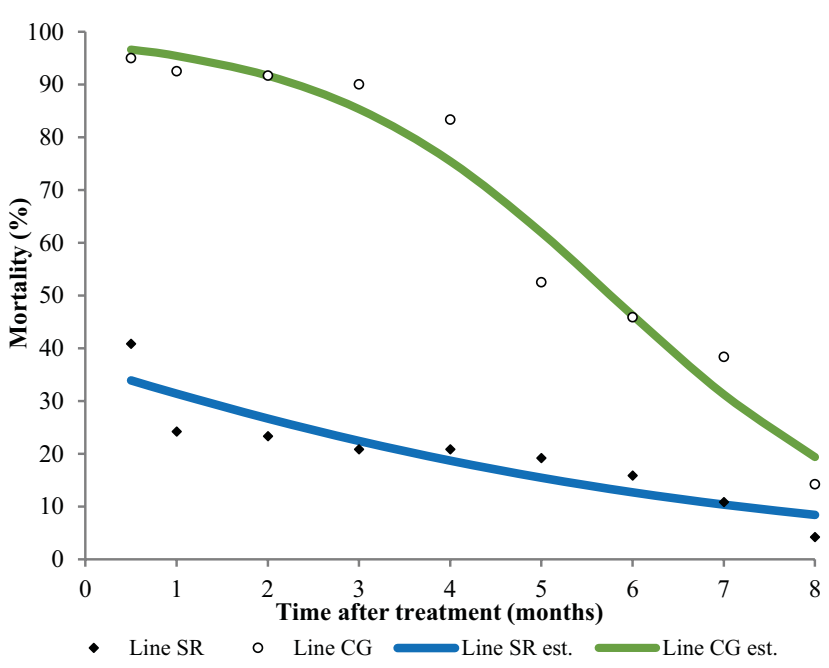

Figure 3. Mortality of two lineages of Rhyzopertha dominica and adjusted curves using the lineagear logistic model over time after treatment of grains with the fenitrothion + esfenvalerate mixture.

pest lineage. Time after treatment is indicated by an $x$ in the expression, and $e(=2.7183)$ is a natural number.

Significant effect $(\mathrm{P}>0.05)$ of lineagear regression was verified in all cases, except for fenitrothion, utilized to control the SR lineage of $R$. dominica $(\mathrm{P}=0.1301)$. This result indicates that time-effect after insecticide application occurred on a number of insects of F1 progeny in seven out of eight combinations of insecticide and pest lineage.

Figures 4 and 5 show tallies observed and adjusted curves of F1 progeny insects, respectively, for each $R$. dominica lineage and each insecticide.

Comparing the four curves of insecticides for each lineage show significant differences $(\mathrm{P}<0.0001)$, for both lineages, indicating the existence of significant differences amid them for at least two insecticides in these populations.

SR lineageage (Fig. 4) report presented an estimated curve over the number of insects of F1 progeny holding higher values than those other treatments; however, this curve was not significantly different from that of the insecticide fenitrothion $(\mathrm{P}=0.1725)$. For the same lineage, esfenvalerate presented the lowest estimated values of response as of the end of the experiment; nevertheless, the estimated curve was not significantly different from that of the fenitrothion + esfenvalerate mixture $(P=0.3081)$. Curves of both insecticides were significantly different from that of control $(\mathrm{P}<$ 0.0001).

As for the CG lineage (Fig. 5), significant differences were observed between all insecticide curves, and the fenitrothion + esfenvalerate mixture was the most effective in reducing F1 progeny. Although fenitrothion was ineffective in controlling

Table 2. Characterization of susceptibility of Rhyzopertha dominica, to insecticides fenitrothion and esfenvalerate via dry film bioassay.

\begin{tabular}{|c|c|c|c|c|c|c|}
\hline Lineage & $\begin{array}{c}\mathrm{LC}_{50} \\
\mu \mathrm{g} \text { de } \mathrm{I} . \mathrm{A} . / \mathrm{mL}\end{array}$ & $\begin{array}{c}\text { Confidence interval } \\
(95 \%)\end{array}$ & $\begin{array}{l}\text { Angular coefficient } \pm \\
\text { standard error }\end{array}$ & $\chi^{2}$ & $\begin{array}{c}\text { D.F. } \\
\mathbf{P}>\mathbf{0 . 0 5}\end{array}$ & Hetero-geneity \\
\hline \multicolumn{7}{|c|}{ Fenitrothion } \\
\hline SR & 2.46 & $2.20-2.74$ & $2.76 \pm 0.17$ & 2.17 & 4 & 0.54 \\
\hline $\mathrm{CG}$ & 1.55 & $1.39-1.74$ & $2.75 \pm 0.20$ & 2.75 & 3 & 0.92 \\
\hline \multicolumn{7}{|c|}{ Esfenvalerate } \\
\hline SR & 1.24 & $0.25-4.46$ & $0.94 \pm 0.07$ & 32.42 & 4 & 8.10 \\
\hline CG & 0.14 & $0.03-0.21$ & $1.74 \pm 0.24$ & 7.45 & 3 & 2.48 \\
\hline
\end{tabular}


Table 3. Deviance analysis for the negative binomial model with logarithmic ligation function of the F1 progeny of Rhyzopertha dominica.

\begin{tabular}{lccc}
\hline \multicolumn{1}{c}{ Causes of variation } & DF & Deviance & $\operatorname{Pr}>\boldsymbol{\chi}^{2}$ \\
\hline Lineage & 1 & 46.28 & $<0.0001$ \\
Insecticide & 3 & 167.83 & $<0.0001$ \\
Lineage $\times$ Insecticide & 3 & 52.60 & $<0.0001$ \\
Month after treatment & 1 & 108.12 & $<0.0001$ \\
Month $\times$ Lineage & 1 & 9.52 & 0.0020 \\
Month $\times$ Insecticide & 3 & 41.81 & $<0.0001$ \\
Month $\times$ Lineage $\times$ Insecticide & 3 & 17.10 & 0.0007 \\
\hline
\end{tabular}

this lineage, it was able to reduce significantly the progeny. Conversely, there was a potentiation effect for the fenitrothion + esfenvalerate mixture in reducing offspring, thus agreeing with the results obtained in the control of parents.

\section{Discussion}

Effectiveness experiments. When insecticides fenitrothion and esfenvalerate were singly utilized the CG strain of $R$. dominica presented the highest mortality \% (Figs. 1 and 2), although the insecticide was able to kill only $60 \%$ of tested individuals as of 15 days after grain treatment. These insecticides caused less than $40 \%$ mortality at any time of the evaluation, that is, SR lineage of $R$. dominica.

The lower locomotion ability of $R$. dominica on grain mass is a characteristic-behavior that favors tolerance of this species because the insect is exposed to a lower amount of insecticide (Surtees 1964). Although $R$. dominica presents great flight ability, it rarely infects grains in the field. The migration of this species occurs mainly from one silo to another (Athié and Paula 2002) and consequently the evolution of resistance might also be favored by this characteristic.

Higher resistance to the tested insecticides was observed in the SR lineage of $R$. dominica compared to the CG lineage. At collection time, the SR lineage of $R$. dominica was more difficult to control than the CG lineage, as after rearing both lineages during 6 years in the absence of selection pressure by insecticides, theoretically a resistance regression was expected in the SR lineage. Nevertheless, the SR lineage was always more resistant than the CG lineage regarding tested insecticides. Hence, results suggest that the SR lineage presents stability of resistance, which would have practical complications to management of this biological phenomenon, because the principle of insecticide-rotation or suspension of the chemical treatment as a management approach is based on the reversion of resistance in the absence of selective pressure. Mason (1998), studying the evolution of resistance of Oryzaephilus surinamensis (L.) (Coleoptera: Silvanidae) to malathion in absence of insecticide, observed different responses in evaluated lineages, existing selection for and against alleles that confer resistance, and possibly in favor of modified alleles that reduce the fitness cost of resistance in an insecticide-free environment.

Differences of susceptibility between the evaluated lineages agree with results obtained by (Pacheco et al. 1993) which did not detect resistance to malathion, nor to pirimiphosmethyl or fenitrothion in populations of $R$. dominica coming from the state of Mato Grosso do Sul, and by Lorini and Galley (1999) who registered moderate to high grounds for resistance to deltamethrinin in populations gathered in Santa Rosa, Rio Grande do Sul. The southern region of the country is a pioneer in storing food grains in bulk, mainly wheat (Puzzi 2000) and the number of storage units in Rio Grande Do Sul is greater than in Mato Grosso do Sul (Beskow and Deckers $2002 b$ ). These characteristics would explain why most cases of insecticide resistance in populations of $R$. dominica originate in the state of Rio Grande do Sul, as an elevated selection pressure for an extended time must have favored the development of this phenomenon.

Some studies have shown a toxic-effect of the additive type (Desmarchelier 1977; Daglish 1998) and potentiate-type (Daglish et al. 1996) when mixing an organophosphate and a pyrethroid insecticide to control coleopteran pests of stored grains. The results obtained in this report indicate that the toxic effect of the mixture of insecticides depends on the molecules involved and, on the species, to be controlled; thus, the mixture of these insecticides for simultaneous control of $R$. dominica and Sitophilus spp. is not always an appropriate strategy.

Reduced movement on treated surface was found in Brazilian lineages of $R$. dominica resistant to deltamethrin (Lorini and Galley 1998; Beckel et al. 2004). This behavioral characteristic would be one responsible for resistance because the insect is exposed to a lower amount of insecticide.

F1 progeny of Rhyzopertha dominica. As expected, fenitrothion failed to reduce the offspring of the SR lineage as it had previously failed in the control of parents. Although fenitrothion and esfenvalerate have caused the same level of control in parents, esfenvalerate significantly reduced progeny, possibly due to the negative effect of this molecule in some aspect of the biology of that lineage. Sub-lethal concentrations of insecticides can cause adverse effects on pest development (Loschiavo 1960; Fila et al. 2003). Instead, no potentiation effect occurred for the fenitrothion + esfenvalerate mixture on progeny reduction, as observed in the control of parents. Thus, offspring reduction for this lineage was exclusively of esfenvalerate effect.

Table 4. F1 progeny of Rhyzopertha dominica. Estimate of $\alpha$ and $\beta$ parameters, of the negative lineagear binomial model, and probability descriptive level for the effect of lineagear regression of time after treatment regarding lineage and insecticide.

\begin{tabular}{lcccccc}
\hline & \multicolumn{3}{c}{ SR lineage } & \multicolumn{2}{c}{ CG lineage } \\
\cline { 2 - 7 } Insecticide & $\boldsymbol{\alpha}$ & $\boldsymbol{\beta}$ & $\begin{array}{c}\text { Lineagear regression } \\
\left(\mathbf{P r}>\chi^{2}\right)\end{array}$ & $\boldsymbol{\alpha}$ & $\boldsymbol{\beta}$ & $\begin{array}{c}\text { Lineagear regression } \\
\left(\mathbf{P r}>\boldsymbol{\chi}^{2}\right)\end{array}$ \\
\hline Control & 4.1223 & 0.1041 & 0.0032 & 4.6064 & 0.0727 & 0.0433 \\
Fenitrothion & 3.6544 & 0.1392 & 0.1301 & 1.8662 & 0.5338 & $<0.0001$ \\
Esfenvalerate & 2.5607 & 0.2434 & 0.0001 & 0.1785 & 0.5737 & $<0.0001$ \\
Fenit + Esfen. & 2.3303 & 0.3507 & $<0.0001$ & 0.1907 & 0.2841 & 0.0003 \\
\hline
\end{tabular}




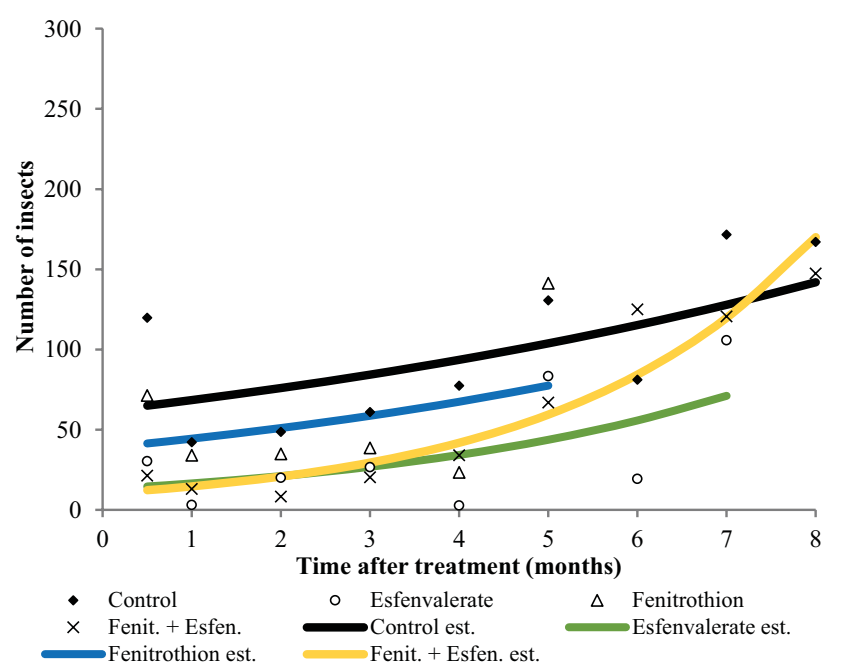

Figure 4. Average observed number of adults (F1) of SR lineage of Rhyzopertha dominica and curves adjusted by the negative binomial model over time after treatment of grains with fenitrothion, esfenvalerate and the fenitrothion + esfenvalerate mixture.

Two important factors to be considered in the control of $R$. dominica are oviposition and feeding habits. This species is characterized by laying eggs on the outside of grains, and after hatching the larvae it perforates the grains and feeds on all its content, reducing them all to empty shells (Athié and Paula 2002). So, most insecticide-susceptible development stages like first-larval and egg being exposed to these chemical products, will be relatively-easily controlled. Instead, surviving larvae feed on the entire content of the grain including the germ tissue where insecticides are concentrated, especially the more lipophilic; consequently, the larvae are killed by exposure to high concentrations of these products. Apparently, this is a disadvantage of the species, as observed in the CG lineage, but the strong selection pressure favors the evolution of resistance and, therefore, the loss of insecticide-effectiveness, as it is observed in the SR lineageage.

When evaluating control treatment, it was verified that the $\mathrm{CG}$ lineage presented greater $\mathrm{F} 1$ progenies than $\mathrm{SR}(\mathrm{P}=$ 0.0001 ), and the inverse occurred when insecticides were applied. The result suggests that when both lineages are reared in the absence of fenitrothion and esfenvalerate, the SR resistant lineage presents adaptive disadvantage compared to that of susceptible CG lineage. Differently, when reared on treated grains, the resistance lineage presented higher adaptive value than the susceptible lineage. The adaptive disadvantage of populations resistant to insecticides in the absence of these chemicals has been demonstrated in some pest species of stored grains (Muggleton 1983; Fragoso et al. 2005). Thus, the effect of insecticide on pest population growth rate depends on the chemical molecule, species, and pest lineage, among other factors.

In the 90's, fenitrothion and esfenvalerate insecticides were effective in the control of $R$. dominica in Brazil (Furiatti et al. 1999), the continuous use of these insecticides without an adequate rotation program has led to the failure of these tools to control the lesser grain borer. On the other hand, cross-resistance between pyrethroids has been demonstrated in populations of $R$. dominica from Brazil (Lorini and Galley 2001). It is likely that the intensive use of other pyrethroids has favored resistance to esfenvalerate.

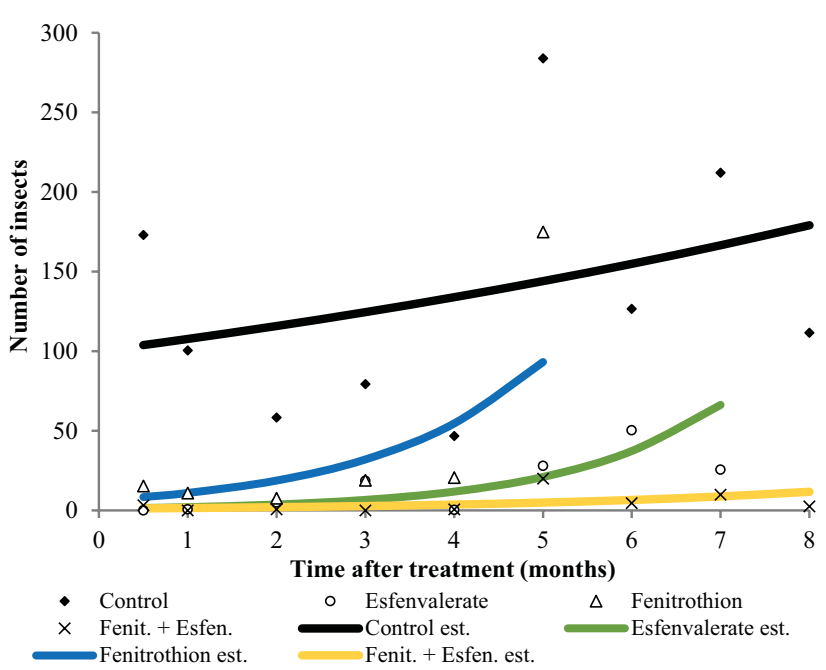

Figure 5. Average observed number of adults (F1) of CG lineage of Rhyzopertha dominica and curves adjusted by the negative binomial model over time after treatment of grains with fenitrothion, esfenvalerate and the fenitrothion + esfenvalerate mixture.

Currently, phosphorus and pyrethroid insecticides have lost efficacy in the control of the lesser grain borer in many countries (Edde 2012). The genetic and bioecological characteristics of this pest added to the inadequate use of insecticides has generated this problem.

Special attention should be given to the fact that both $R$. dominica populations were reared for more than six years in the absence of any insecticide. In the case of the SR lineage, the resistance remained stable despite the years that passed. This shows that both insecticides are not viable for the control of $R$. dominica and must be temporarily removed from the control programs of this pest in Brazil.

\section{Conclusions}

The population of $R$. dominica from Santa Rosa (SR lineage) is highly resistant to fenitrothion and esfenvalerate and its population growth is stimulated by these insecticides (hormoligosis). On the other hand, the population from Campo Grande (CG lineage) is not efficiently controlled either, but its population growth is negatively affected by the insecticides studied. The present work shows the serious problem in the control of $R$. dominica, the main pest of stored wheat in Brazil, using traditional insecticides, such as fenitrothion and esfenvalerate. In this scenario, it is recommended to study the effectiveness of insecticides from other chemical groups, diatomaceous earth, botanical insecticides and fumigants, as well as the implementation of integrated pest management programs.

\section{Literature cited}

ADELSBACH, T. L.; TJEERDEMA, R. S. 2003. Chemistry and fate of fenvalerate and esfenvalerate. Reviews of Environmental Contamination and Toxicology 176: 137-154. https://doi. org/10.1007/978-1-4899-7283-5_3

AFFUL, E.; ELLIOTT, B.; NAYAK, M. K.; PHILLIPS, T. W. 2018. Phosphine resistance in North American field populations of the lesser grain borer, Rhyzopertha dominica (Coleoptera: Bostrichidae). Journal of Economic Entomology 111 (1): 463-469. https:// doi.org/10.1093/jee/tox284

AGÊNCIA NACIONAL DE VIGILÂNCIA SANITÁRIA. 2020a. F05-Fenitrotiona. Agência Nacional de Vigilância Sanitária. 
Available in: https://www.gov.br/anvisa/pt-br/setorregulado/regularizacao/agrotoxicos/monografias/monografias-autorizadas/ f/4330json-file-1/view. [Review date: 24 November 2020]

AGÊNCIA NACIONAL DE VIGILÂNCIA SANITÁRIA. 2020 b. E18-Esfenvalerato. Agência Nacional de Vigilância Sanitária. Available in: https://www.gov.br/anvisa/pt-br/setorregulado/ regularizacao/agrotoxicos/monografias/monografias-autorizadas/e/4314json-file-1/view. [Review date: 24 November 2020]

ARTHUR, F. H. 1999. Knockdown, mortality, and progeny production of lesser grain borers (Coleoptera: Bostrichidae) and rice weevils (Coleoptera: Curculionidae) exposed for short intervals on wheat treated with cyfluthrin. Journal of Economic Entomology 92 (5): 1198-1205. https://doi.org/10.1093/jee/92.5.1198

ATHANASSIOU, C. G. 2006. Toxicity of beta cyfluthrin applied alone or in combination with diatomaceous earth against adults of Sitophilus oryzae (L.) (Coleoptera: Curculionidae) and Tribolium confusum DuVal (Coleoptera: Tenebrionidae) on stored wheat. Crop Protection 25 (8): 788-794. https://doi.org/10.1016/j. cropro.2005.10.015

ATHIÉ, I.; PAULA, D. C. 2002. Insetos de grãos armazenados: aspectos biológicos e identificação. 2nd Edition. Varela, São Paulo, Brazil. 244 p.

BECKEL, H.; LORINI, I.; LÁZZARI, S. M. N. 2004. Comportamento de adultos de diferentes raças de Rhyzopertha dominica (Fabricius) (Coleoptera, Bostrichidae) em superfície tratada com deltamethrin. Revista Brasileira de Entomologia 48 (1): 115-118. https://doi.org/10.1590/S0085-56262004000100019

BENGSTON, M.; DESMARCHELIER, J. M.; HAYWARD, B.; HENNING, R.; MOUDEN, J. H.; NOBLE, R. M.; SMITH, G.; SNELSON, J. T.; STICKA, R.; THOMAS, D.; WALLBANK, B. E.; WEBLEY, D. J. 1987. Synergised cyfluthrin and cypermethrin as grain protectants on bulk wheat. Pesticide Science 21 (1): 23-37. https://doi.org/10.1002/ps.2780210103

BESKOW, P.; DECKERS, D. 2002a. Legislação brasileira de armazenamento de grãos. pp. 27-53. In: Lorini, I.; Miike, L. H.; Scussel, V. M. (Eds.). Armazenagem de grãos. Instituto Bio Geneziz, Campinas, Brazil. 1000 p.

BESKOW, P.; DECKERS, D. 2002b. Capacidade brasileira de armazenagem de grãos. pp. 99-115. In: Lorini, I.; Miike, L. H.; Scussel, V. M. (Eds.). Armazenagem de grãos. Instituto Bio Geneziz, Campinas, Brazil. 1000 p.

CHAMP, B. R.; STEELE, R. W.; GENN, B. G.; ELMS, K. D. 1969. A comparison of malathion, diazinon, fenitrothion and dichlorvos for control of Sitophilus oryzae (L.) and Rhyzopertha dominica (F.) in wheat. Journal of Stored Products Research 5 (1): 21-48. https://doi.org/10.1016/0022-474X(69)90023-X

COLLINS, P. J.; LAMBKIN, T. M.; BRIDGEMAN, B. W.; PULVIRENTI, C. 1993. Resistance to grain-protectant insecticides in coleopterous pests of stored cereals in Queensland, Australia. Journal of Economic Entomology 86 (2): 239-245. https://doi. org/10.1093/jee/86.2.239

DAGLISH, G. J. 1998. Efficacy of six grain protectants applied alone or in combination against three species of coleoptera. Journal of Stored Products Research 34 (4): 263-268. https://doi. org/10.1016/S0022-474X(98)00007-1

DAGLISH, G. J.; EELKEMA, M.; HARRISON, L. M. 1996. Control of Sitophilus oryzae (L.) (Coleoptera: Curculionidae) in paddy rice using chlorpyrifos-methyl or fenitrothion in combinations with several other protectants. Journal of Stored Products Research 32 (3): 247-253. https://doi.org/10.1016/S0022474X(96)00013-6

DAGLISH, G. J.; WALLBANK, B. E. 2005. Efficacy of diflubenzuron plus methoprene against Sitophilus oryzae and Rhyzopertha dominica in stored sorghum. Journal of Stored Products Research 41 (3): 353-360. https://doi.org/10.1016/j.jspr.2004.06.001

DESMARCHELIER, J. M. 1977. Selective treatments, including combinations of pyrethroid and organophosphorus insecticides, for control of stored product Coleoptera at two temperatures.
Journal of Stored Products Research 13 (3): 129-137. https://doi. org/10.1016/0022-474X(77)90011-X

EDDE, P. A. 2012. A review of the biology and control of Rhyzopertha dominica (F.) the lesser grain borer. Journal of Stored Products Research 48: 1-18. https://doi.org/10.1016/j.jspr.2011.08.007

EVANS, N. J. 1985. The effectiveness of various insecticides on some resistant beetle pests of stored products from Uganda. Journal of Stored Products Research 21 (2): 105-109. https://doi. org/10.1016/0022-474X(85)90030-X

FILA, K.; ADAMSKI, Z.; ZIEMNICKI, K. 2003. Exposure to fenitrothion causes malfunctions of Spodoptera exigua Hübn. (Lep., Noctuidae) eggs. Journal of Applied Entomology 126 (2-3): 114-118. https://doi.org/10.1046/j.1439-0418.2002.00623.x

FRAGOSO, D. B.; GUEDES, R. N. C.; REZENDE, S. T. 2003. Glutathione S-transferase detoxification as a potential pyrethroid resistance mechanism in the maize weevil, Sitophilus zeamais. Entomologia Experimentalis et Applicata 109 (1): 21-29. https:// doi.org/10.1046/j.1570-7458.2003.00085.x

FRAGOSO, D. B.; GUEDES, R. N. C.; PETERNELLI, L. A. 2005. Developmental rates and population growth of insecticide-resistant and susceptible populations of Sitophilus zeamais. Journal of Stored Products Research 41 (3): 271-281. https://doi.org/10.1016/j.jspr.2004.03.008

FURIATTI, R. S.; PEREIRA, P. R. V. S.; PINTO Jr., A. R.; LAZZARI, F. A. 1999. Avaliação de inseticidas no controle de Sitophilus oryzae (Linnaeus) (Coleoptera: Curculionidae) e Rhyzopertha dominica (Fabricius) (Coleoptera: Bostrichidae) em trigo armazenado. Revista Brasileira de Zoologia 16 (1): 221-226. https:// doi.org/10.1590/S0101-81751999000100018

GALLO, D.; NAKANO, O.; SILVEIRA, S.; CARVALHO, R. P. L.; BAPTISTA, G. C.; BERTI FILHO, E.; PARRA, J. R. P.; ZUCCHI, R. A.; ALVES, S. B.; VENDRAMIM, J. D.; MARCHINI, L. C.; LOPES, J. R. S.; OMOTO, C. 2002. Entomología agrícola. FEALQ, Piracicaba, 920 p.

GUEDES, R. N. C.; ZHU, K. Y. 1999. Characterization of malathion resistance in a Mexican population of Rhyzopertha dominica. Pesticide Science 53 (1): 15-20. https://doi.org/10.1002/(SICI)1 096-9063(199805)53:1<15::AID-PS746>3.0.CO;2-Q

GUEDES, R. N. C.; DOVER, B. A.; KAMBHAMPATI, S. 1996. Resistance to chlorpyrifos-methyl, pirimiphos-methyl, and malathion in Brazilian and U.S. populations of Rhyzopertha dominica (Coleoptera: Bostrichidae). Journal of Economic Entomology 89 (1): 27-32. https://doi.org/10.1093/jee/89.1.27

GUEDES, R. N. C.; KAMBHAMPATI, S.; DOVER, B. A.; ZHU, K. Y. 1997. Biochemical mechanisms of organophosphate resistance in Rhyzopertha dominica (Coleoptera: Bostrichidae) populations from the United States and Brazil. Bulletin of Entomological Research 87 (6): 581-586. https://doi.org/10.1017/ S0007485300038670

HYARI, S.; KADOUM, A. M.; LAHUE, D. W. 1977. Laboratory evaluations of emulsifiable and encapsulated formulations of malathion and fenitrothion on soft red winter wheat against attack by adults of four species of stored product insects. Journal of Economic Entomology 70 (4): 480-482. https://doi.org/10.1093/ jee $/ 70.4 .480$

KUENEN, D. J. 1958. Influence of sublethal doses of DDT upon the multiplication rate of Sitophilus granarius (Coleoptera: Curculionidae). Entomologia Experimentalis et Applicata 1 (2): 147152. https://doi.org/10.1111/j.1570-7458.1958.tb00018.x

LEORA SOFTWARE COMPANY. 2016. Polosuite: a user's guide to probit or logit analysis. LeOra Software Company, Berkeley, CA. EE. UU.

LORINI, I.; GALLEY, D. J. 1998. Relative effectiveness of topical, filter paper and grain applications of deltamethrin, and associated behaviour of Rhyzopertha dominica (F.) strains. Journal of Stored Products Research 34 (4): 377-383. https://doi.org/10.1016/ S0022-474X(98)00023-X

LORINI, I.; GALLEY, D. J. 1999. Deltamethrin resistance in Rhyzopertha dominica (F.) (Coleoptera: Bostrichidae), a pest of sto- 
red grain in Brazil. Journal of Stored Products Research 35 (1): 37-45. https://doi.org/10.1016/S0022-474X(98)00028-9

LORINI, I.; GALLEY, D. J. 2001. The cross-resistance spectrum in Deltamethrin resistance strains of Rhyzopertha dominica (F.) (Coleoptera: Bostrichidae). Neotropical Entomology 30 (2): 321-325. https://doi.org/10.1590/S1519-566X2001000200018

LOSCHIAVO, S. R. 1960. Effects of low doses of ethylene dibromide on some stages of the confused flour beetle, Tribolium confusum. Journal of Economic Entomology 53 (5): 762-767. https:// doi.org/10.1093/jee/53.5.762

LUCKEY, T. D. 1968. Insecticide hormoligosis. Journal of Economic Entomology 61 (1): 7-12. https://doi.org/10.1093/jee/61.1.7

MASON, P. L. 1998. Selection for and against resistance to insecticides in the absence of insecticide: a case study of malathion resistance in the saw-toothed grain beetle, Oryzaephilus surinamensis (Coleoptera: Silvanidae). Bulletin of Entomological Research 88 (2): 177-188. https://doi.org/10.1017/S0007485300025748

MORSE, J. G. 1998. Agricultural implications of pesticide-induced hormesis of insects and mites. Human \& Expimental Toxicology 17 (5): 266-269. https://doi.org/10.1177/096032719801700510

MUGGLETON, J. 1983. Relative fitness of malathion- resistant phenotypes of Oryzaephilus surinamensis L. (Coleoptera: Silvanidae). Journal of Applied Ecology 20 (1): 245-254. https://doi. org/10.2307/2403390

PACHECO, I. A.; SARTORI, M. R.; BOLONHEZI, S. 1991. Resistance to malathion, pirimiphos-methyl and fenitrothion in coleoptera from stored grains. pp. 1029-1038. In: Fleurat-Lessard, F.; Ducom, P. (Eds.). Proceedings of the 5th International Working Conference on Stored-Product Protection, 9-14 september 1990, Bordeaux, France. 2064 p.

PACHECO, I. A.; SARTORI, M. R.; BOLONHEZI, S. 1993. Resistência ao malation, pirimifós-metílico e ao fenitrotion em coleopteros-praga de grãos armazenados - fase II. Revista Brasileira de Armazenamento 18: 32-39.

PAUDYAL, S.; OPIT, G. P.; ARTHUR, F. H.; BINGHAM, G. V.; GAUTAM, S. G. 2016. Contact toxicity of deltamethrin against Tribolium castaneum (Coleoptera: Tenebrionidae), Sitophilus oryzae (Coleoptera: Curculionidae), and Rhyzopertha dominica (Coleoptera: Bostrichidae) adults. Journal of Economic Entomology 109 (4): 1936-1942. https://doi.org/10.1093/jee/tow 107

PEREIRA, P. R.V. S.; FURIATTI, R. S.; LAZZARI, F. A.; PINTO-JR, A. R. 1997. Avaliação de inseticidas no controle de Sitophilus oryzae (L.) (Coleoptera: Curculionidae), e Rhyzopertha dominica (Fab.) (Coleoptera: Bostrichidae) em milho armazenado. Anais da Sociedade Entomológica do Brasil 26 (3): 411-416. https://doi.org/10.1590/S0301-80591997000300001

PINTO Jr., A. R.; FURIATTI, R. S.; PEREIRA, P. R.V.S.; LAZZARI, F. A. 1997. Avaliação de inseticidas no controle de Sitophilus oryzae (L.) (Coleoptera: Curculionidae), e Rhyzopertha dominica (Fab.) (Coleoptera: Bostrichidae) em arroz armazenado. Anais da Sociedade Entomológica do Brasil 26 (2): 285-290. https://doi.org/10.1590/S0301-80591997000200009

PUZZI, D. 2000. Abastecimento e armazenagem de grãos. 2nd Edition. Instituto Campineiro de Ensino Agrícola, Campinas, Brasil, 666 p.

RIBEIRO, B. M.; GUEDES, R. N. C.; OLIVEIRA, E. E.; SANTOS, J. P. 2003. Insecticide resistance and synergism in Brazilian populations of Sitophilus zeamais (Coleoptera: Curculionidae). Journal of Stored Products Research 39 (1): 21-31. https://doi. org/10.1016/S0022-474X(02)00014-0
SAS INSTITUTE. 1999. SAS/STAT User's guide 8.0. Cary, 1999. $1 \mathrm{CD}-\mathrm{ROM}$.

STARK, J. D.; BANKS, J. E. 2003. Population-level effects of pesticides and other toxicants on arthropods. Annual Review of Entomology 48: 505-519. https://doi.org/10.1146/annurev. ento.48.091801.112621

SURTEES, G. 1964. Laboratory studies on dispersion behavior of adult beetles in grain. IV.- The lesser grain borer, Rhyzopertha dominica (F.) (Coleoptera, Bostrichidae). Bulletin of Entomological Research 54 (4): 715-722. https://doi.org/10.1017/ S0007485300049130

THAUNG, M.; COLLINS, P. J. 1986. Joint effects of temperature and insecticides on mortality and fecundity of Sitophilus oryzae (Coleoptera: Curculionidae) in wheat and maize. Journal of Economic Entomology 79 (4): 909-914. https://doi.org/10.1093/ jee/79.4.909

VÁSQUEZ-CASTRO, J. A.; BAPTISTA, G. C.; GADANHA Jr., C. D.; TREVIZAN, L. R. P. 2007a. A system to evaluate the performance of hydraulic nozzles used in stored grain protection trials. Scientia Agricola 64 (6): 563-568. https://doi.org/10.1590/ S0103-90162007000600001

VÁSQUEZ-CASTRO, J. A.; BAPTISTA, G. C.; GADANHA, C. D.; TREVIZAN, L. R. P. 2007b. Influence of emulsifiable concentrate formulation on the physical properties of the fluid, spray characteristics, and insecticide deposits on stored grains. Journal of Agricultural and Food Chemistry 55 (9): 3529-3534. https:// doi.org/10.1021/jf063225n

VÁSQUEZ-CASTRO, J. A.; BAPTISTA, G. C.; GADANHA, C. D.; TREVIZAN, L. R. P. 2012. Insecticidal effect and residual action of fenitrothion and esfenvalerate on Sitophilus oryzae and S. zeamais (Coleoptera: Curculionidae) in stored maize and wheat. International Scholarly Research Notices - ISRN Agronomy 2012: 158179. https://doi.org/10.5402/2012/158179

VÁSQUEZ-CASTRO, J.; DE BAPTISTA, G.; GADANHA-JUNIOR, C.; BRACHO-PÉREZ, J. 2020. Dissipation of fenitrothion and esfenvalerate in wheat grains, bran and flour. Peruvian Journal of Agronomy 4 (2): 40-47. http://doi.org/10.21704/pja. v4i2.1510

\section{Origin and funding}

The present research was carried out for the authors'own interest to study the resistance to insecticides in one of the most important pests of stored grains in Brazil. The financing was granted by the Laboratory for the Analysis of Pesticide Residue of the Escola Superior de Agricultura "Luiz de Queiroz", Universidade de São Paulo, Brazil.

\section{Author contribution}

Javier Alberto Vásquez-Castro, raised the pest, executed the bioassays and wrote the article.

Gilberto Casadei de Baptista, worked in the direction of the research and wrote the article.

Casimiro Dias Gadanha Jr., worked on the technology of application of insecticides on the mass of grains.

Julio César Bracho-Pérez, worked on the collection of $\underline{R}$. dominica populations and did the statistical analysis of the data. 